\title{
ORZECZNICTWO DOTYCZĄCE CZASU W PRAWIE
}

Slowa kluczowe: czas w procedurze i prawie karnym

Wyrok SN z dnia 09.03.2009 r., II KK 32/09, LEX nr 491308

Osąadzenie i skazanie oskarżonej jak osoby dorosłej za czyn nienależący do katalogu przestępstw z art. $10 \S 2 \mathrm{kk}$. w myśl reguł przewidzianych w Kodeksie karnym w sytuacji, gdy jej odpowiedzialność powinna kształtować się stosownie do zasad określonych w ustawie z dnia 26 października 1982 r. o postępowaniu w sprawach nieletnich (tekst jedn.: Dz.U. z 2002 r. Nr 11, poz. 109) i wymierzenie, nieletniej wówczas oskarżonej, kary ograniczenia wolności przewidzianej w Kodeksie karnym stanowi oczywiste i rażące naruszenie prawa materialnego

\section{Wyrok SN z dnia 19.12.2009 r., III KK 449/02, LEX nr 74425}

Zgodnie z brzmieniem art. $10 \S 1$ kk., zasady odpowiedzialności karnej nie dotyczą osób, które nie ukończyły 17 lat.

\section{Wyrok SN z dnia 4 marca 2002 r., V KKN 124/00, LEX nr 53061}

Obowiązujący kodeks postępowania karnego nie wymienia wśród zamkniętego katalogu podstaw oddalenia wniosku dowodowego - art. $170 \S 1 \mathrm{kpk}$. - przewlekania postępowania karnego.

\section{Wyrok SN z dnia 1 kwietnia 1988 r., IV KR 281/87, OSNKW 1988/9-10/69}

Nie jest dopuszczalna w świetle art. $155 \S 1$ i $3 \mathrm{kpk}$. odmowa przeprowadzenia dowodu z opinii o stanie zdrowia psychicznego oskarżonego (art. $183 \mathrm{kpk}$.) w rozpoznawanej sprawie tylko na tej podstawie, że w innej sprawie toczącej się wcześniej i przed innym sądem o inny czyn biegli lekarze psychiatrzy nie stwierdzili zniesionej lub ograniczonej w stopniu znacznym poczytalności oskarżonego.

\section{Wyrok SN z dnia 15 kwietnia 1976 r., II KR 48/76, OSNKW 1976/10-11/133}

Do wiadomości specjalnych, którego to pojęcia używa art. $176 \S 1$ kpk., nie należą te wiadomości, które są dostępne dla dorosłego człowieka o odpowiednim doświadczeniu życiowym, wykształceniu i zasobie wiedzy ogólnej. 


\section{Postanowienie SN z dnia 16.02.2006 r., V KK 463/05, LEX nr 181028}

Fakt, że art. $10 \S 2 \mathrm{kk}$. przewiduje możliwość orzeczenia przez sąd również środków przewidzianych $\mathrm{w}$ ustawie o postępowaniu w sprawach nieletnich, nie daje żadnych podstaw do oceny, że ich niezastosowanie prowadzi do obrazy prawa materialnego.

\section{Postanowienie SN z dnia 11.10.2006 r., IV KK 164/06, OSNwSK 2006/1/1910}

Gdy chodzi o sprawców nieletnich, przewidziany w art. $10 \S 3 \mathrm{kk}$. nakaz, że kara nie może przekroczyć dwóch trzecich górnego zagrożenia, odnieść trzeba w wypadku przestępstwa zabójstwa do kary dożywotniego pozbawienia wolności, a nie kary 25 lat pozbawienia wolności.

Zawarty w art. $54 \S 2 \mathrm{kk}$. zakaz orzekania wobec sprawcy, który w czasie popełnienia nie ukończył 18 lat kary dożywotniego pozbawienia wolności, nie wyklucza wymierzenia nieletniemu, odpowiadającemu w warunkach art. $10 \S 2$ za przestępstwo zagrożone taką karą-25 lat pozbawienia wolności.

\section{Postanowienie SN z dnia 04.05.2005 r., II KK 454/04, LEX nr 149647}

1. Art. $54 \S 1$ kk. nie eliminuje zasad wymiaru kary określonych w art. 53 kk., a jedynie na pierwszym miejscu spośród wymienionych w tym przepisie dyrektyw stawia względy wychowawcze. Zatem „młodocianość” i „względy wychowawcze” nie mają samodzielnego bytu jako podstawa szczególnego kształtowania wymiaru kary (złagodzenia kary), a stanowią jedynie punkt wyjściowy i muszą być zestawione z pozostałymi okolicznościami podmiotowymi i przedmiotowymi, mającymi znaczenie dla wymiaru kary. Przy tym istotnymi przesłankami przy ustalaniu kary młodocianemu sprawcy winien być stopień jego zdemoralizowania, tryb życia przed popełnieniem przestępstwa, zachowanie się po jego popełnieniu, motywy i sposoby działania. Czynniki te mogą przeważyć tak dalece, iż zasadne będzie wymierzenie nawet bardzo młodemu wiekiem sprawcy kary w górnych granicach ustawowego zagrożenia.

2. Górną granicę ustawowego zagrożenia określają wyłącznie przepisy części szczególnej kodeksu karnego lub innych ustaw. Przewidziany obowiązek wymierzania nieletnim kary nieprzekraczającej dwóch trzecich ustawowego zagrożenia należy zatem odnosić do kary dożywotniego pozbawienia wolności, a nie kary 25 lat pozbawienia wolności. 


\section{Wyrok Sądu Apelacyjnego w Lublinie z dnia 6 lutego 2002 r., II AKa 222/01, Wokanda 2002/5/46}

Składanie przez oskarżonego lub jego obrońcę licznych bezzasadnych wniosków dowodowych odnośnie do okoliczności, które znane były oskarżonemu lub jego obrońcy już w chwili zakończenia postępowania przygotowawczego, składanie tych wniosków na ostatniej rozprawie kończącej bardzo długo toczące się postępowanie jurysdykcyjne - świadczy ewidentnie o dążeniu do obstrukcji procesowej. Prawo do obrony traktowane jest tutaj instrumentalnie, w sposób służący utrudnieniu sprawnego przebiegu procesu, a nie jako prawo do wykazywania niewinności oskarżonego. Nie należy dopuszczać do tego, ażeby nadużycie instrumentów procesowych przez uczestników procesu miało doprowadzić do zablokowania procesu karnego lub jego wykolejenia.

\section{Wyrok Sądu Apelacyjnego w Krakowie z dnia 12 listopada 1998 r., II AKa 199/98, KZS 1998/12/35}

Niedopuszczalne jest oddalenie wniosku dowodowego dlatego, że ,zmierza do przewlekłości postępowania”, gdyż taki powód nie jest przewidziany przez ustawę (art.170 § 1 kpk.). Nawet późno złożony wniosek może przyczynić się do ustalenia istotnej dla wyrokowania okoliczności. Inną rzeczą jest stymulowanie dyscypliny procesowej stron, a w tym i zaostrzenie kary z powodu obrony wykrętnej, utrudniającej postępowanie.

Teza częściowo nieaktualna - spr. art. 170 § 1 pkt 5 kpk.

\section{Postanowienie Sądu Apelacyjnego w Krakowie z dnia 20 maja 2008 r., II AKZ 236/08, Prokuratura i Prawo - wkładka 2009/1/40}

Obliczanie terminów stosowania tymczasowego aresztowania dokonuje się według czasu kalendarzowego, w sposób przewidziany w art. $123 \S 2$ kpk., a poprzednio w art. 108 kpk. z 1969 roku i w art. $41 \S 2$ kk. z 1932 roku, pierwszej polskiej regulacji tego przedmiotu. Nie ma istotnego znaczenia, że czas aresztowania w lutym nie zawsze jest równy, a czas w lipcu i sierpniu wynosi 62 dni, gdy w niektórych innych miesiącach jest krótszy. Jest to pochodna założeń kalendarza gregoriańskiego, którego zgodność z Konstytucją RP nie podlega badaniu, zaś podważanie jego założeń prowadziłoby na manowce. 


\section{Słowa kluczowe: Czas i skutki jego upływu w prawie i postępowaniu cywilnym}

\section{Wyrok TK z dnia 1 września 2006 r., SK 14/05, OTK-A 2006/8/97}

\section{Z uzasadnienia:}

„Ustawodawstwo polskie, podobnie jak wiele obcych systemów prawnych, zna w sferze stosunków prywatnoprawnych rozwiązania służące uwzględnieniu zmiennych okoliczności faktycznych. Chodzi o takie instytucje, które najogólniej rzecz ujmując, służą zapewnieniu pewności obrotu i realizacji postulatu, aby stan prawny pozostawał w zgodności ze stanem rzeczywistym. Ponadto nowoczesne prawodawstwa cywilne - poza specyficzną i podlegającą szczególnej ochronie instytucją cywilnoprawna, jaką jest prawo własności - starają się eliminować sytuacje, które umożliwiałyby istnienie trwałych i nierozwiązywalnych stosunków prawnych między pewnymi podmiotami. Rozwiązaniami służącymi m.in. osiagnnięciu tych celów są instytucje prawne mieszczące się w ramach ogólnego rozwiązania określanego mianem dawności. Należy do nich przedawnienie, które w polskim kodeksie cywilnym z 1964 r. zostało unormowane jako odnoszące się wyłącznie do roszczeń majątkowych. Można powiedzieć, że zasadą ogólną polskiego prawa cywilnego jest to, iż roszczenia majątkowe ulegają po pewnym czasie przedawnieniu, tj. że z jego upływem osoba obowiązana może uchylić się od spełnienia obowiązku, który odpowiada treści roszczenia.

Nie ulega wątpliwości, że roszczenia odszkodowawcze, przysługujące co do zasady poszkodowanemu przeciwko sprawcy szkody, jako odnoszące się do sfery majątkowej, a zatem jako roszczenia majątkowe, także ulegają przedawnieniu."

„W doktrynie zauważa się również wyraźnie potrzebę uwzględnienia szczególnego charakteru szkód na osobie. Ich swoistość, ściśle związana z psychofizycznymi właściwościami każdej osoby, powinna skłaniać do odmiennego traktowania czynów niedozwolonych, wywołujących tego typu szkodę (por. T. Dybowski, Glosa do wyroku SN 21 maja 2003, sygn. akt IV CKN 378/01, PS 2005/6/136-137).

Chodzi bowiem nie o uszczerbek w określonych dobrach majątkowych osoby, lecz o nią samą, uszczerbek, który zazwyczaj, przynajmniej pośrednio, nie pozostaje bez przemożnego wpływu na jej dalsze życie w wielu jego wymiarach, możliwości rozwoju zdolności, realizacji aspiracji i ambicji, perspektywy realizacji zamierzeń zarówno w życiu zawodowym, jak i osobistym czy wreszcie po prostu możliwości uzyskania środków utrzymania w analizowanych sytuacjach związanych z niemożnością podniesienia roszczenia, które się przedawniło, zanim powstało. Nawet oceniając rzecz intuicyjnie, łatwo jest dojść do przekonania, że odjęcie takiej osobie możliwości poszukiwania rekompensaty doznanych szkód jest niesprawiedliwe 
(co zresztą dostrzega także Sąd Najwyższy w uchwale pełnego składu Izby Cywilnej z 17 lutego 2006 r.)

Szkoda na osobie jest w prawie cywilnym poddana szczególnym regulacjom ochronnym, które realizują na tym odcinku generalne założenia aksjologiczne systemu prawa. Obok rozbudowanych środków ochrony majątkowej (jednorazowe odszkodowanie, renta wyrównawcza, renta z powodu utraty widoków na przyszłość) dla samego poszkodowanego (art. $444 \mathrm{kc}$.) i jego bliskich (art. $446 \mathrm{kc}$.) przewidywane są instrumenty kompensacji krzywdy niemajątkowej (por. art. 445 i art. 448 kc.). Kompensacja szkody na osobie jest przedmiotem wyjątkowego instrumentu ochronnego, jakim jest realizacja odpowiedzialności na podstawie zasad słuszności (art. $4172 \mathrm{kc}$.). Nie można wreszcie nie zauważyć, że reguły naprawienia szkody na osobie poddane są jednolitej konstrukcji prawnej, bez względu na przesłanki, na których opiera się odpowiedzialność odszkodowawcza.

Dyferencjacja mechanizmu przedawnienia w odniesieniu do realizacji roszczeń odszkodowawczych z tytułu szkody na osobie byłaby więc nie tylko wyłomem w dotychczasowych, tradycyjnie ukształtowanych regułach odpowiedzialności cywilnej, ale także trudna do pogodzenia $z$ realizowaną aksjologią rozwiązań prawnych, mającą mocne oparcie w zasadzie konstytucyjnej zawartej w art. 30 .

W konsekwencji uwagi te prowadzą do stwierdzenia, że swoista fikcyjność prawa majątkowego, powstającego po stronie poszkodowanego ze względu na wadliwość mechanizmu przedawnienia w art. $442 \mathrm{kc}$., narusza wartości zakodowane w art. 30 Konstytucji.

Zdaniem Trybunału Konstytucyjnego celowość skutecznej ochrony interesów jednostki związanych ze szkodą na osobie, poprzez odpowiednie ukształtowanie mechanizmu przedawnienia roszczeń odszkodowawczych, powinna być więc uwzględniana w każdym wypadku szkody na osobie wyrządzonej czynem niedozwolonym. Takie stanowisko nie podważa trafności przytoczonej wcześniej argumentacji, w świetle której ocena wadliwości mechanizmu przedawnienia $\mathrm{z}$ art. 442 kc. uzyskuje dodatkowe, szczególnie mocne oparcie w stosunku do szkody wyrządzonej czynem niedozwolonym władzy publicznej - na tle art. 77 ust. 1 Konstytucji."

„Na marginesie jedynie można zauważyć, że pojawiają się przede wszystkim w orzecznictwie próby ochrony poszkodowanego przez sięgnięcie po instrument w postaci powództwa o ustalenie (art. $189 \mathrm{kpc}$.) czy nadużycia prawa podmiotowego (art. 5 kc., por. m.in. wyrok SN z 8 listopada 2002 r., sygn. akt III CKN 1115/00, Lex nr 75288; zob. uwagi M. Warcińskiego, glosa do wyroku Sądu Najwyższego z 16 marca 2005 r., jw., s. 274). Są to jednak rozwiązania o nieporównywalnie mniejszej skuteczności i pewności w stosunku do właściwej regulacji na gruncie samej konstrukcji przedawnienia roszczeń, której wprowadzenia domaga się skarżący. 
Obie instytucje w żadnej mierze nie dostarczają efektywnego i pewnego instrumentu, który mógłby służyć osiagnnięciu przez poszkodowanego w normalnych okolicznościach celu, jakim jest uzyskanie świadczenia odszkodowawczego.

Trudno też uznać za wystarczające, a nawet możliwe wytoczenie przez poszkodowanego swoistego ,prewencyjnego" powództwa o „ustalenie” przyszłych szkód. Dotyczy to w szczególności szkód na osobie. Ustawodawca nie może w ocenie Trybunału wprowadzać takich rozwiązań ustawowych, które w oczywisty sposób w pewnych sytuacjach (a należy je uznać na tle rozwoju nauk przyrodniczych i nowoczesnych technologii za coraz bardziej prawdopodobne) prowadzą do zwolnienia sprawcy szkody z odpowiedzialności i pozostawiają poszkodowanego bez szans na uzyskanie choćby częściowej rekompensaty."

„Należy jednak zwrócić uwagę, że przedawnienie w prawie polskim nie zostało unormowane w sposób jednolity. Termin i początek jego biegu jest różnie unormowany przez obowiązujące ustawodawstwo, w zależności od charakteru stosunku prawnego, z którego wynika roszczenie, a także przede wszystkim konieczności uwzględnienia określonych czynników przemawiających za właściwym zbalansowaniem interesów zainteresowanych. Zdaniem Trybunału Konstytucyjnego instrument w postaci dawności powinien zawsze równoważyć różne, zazwyczaj sprzeczne interesy uczestników obrotu cywilnoprawnego. Nie mogą w systemie prawnym istnieć unormowania, które umożliwiają dochodzenie praw czy ich wykonywanie $\mathrm{z}$ jednoczesnym nałożeniem na inne podmioty obowiązków im odpowiadających $a d$ infinitum, przez czas nieokreślony, oraz takie, które powodują permanentny stan niepewności co do rzeczywistego stanu prawnego. W analizowanym jednak wypadku istota problemu nie dotyczy tego, jak długi powinien być termin przedawnienia, lecz tego, od kiedy należy liczyć bieg terminu dawności, a zatem ukształtowania samego mechanizmu jego obliczania."

\section{Uchwała SN z dnia 4 grudnia 2009 r., III CZP 97/09, Biuletyn SN 2009/12/6}

Prawomocny wyrok oddalający powództwo o ustalenie na przyszłość odpowiedzialności pozwanego za skutki czynu niedozwolonego ze względu na upływ terminu przedawnienia określonego $\mathrm{w}$ art. $442 \S 1$ zdanie drugie kc. wiąże sąd na podstawie art. $365 \S 1 \mathrm{kpc}$. w sprawie o naprawienie szkód ujawnionych po wejściu w życie art. $4421 \mathrm{kc}$.

\section{Uchwała SN z dnia 17 lutego 2006 r., III CZP 84/05, OSNC 2006/7-8/114}

Roszczenie o naprawienie szkody wyrządzonej czynem niedozwolonym przedawnia się z upływem lat dziesięciu od dnia, w którym nastapiło zdarzenie wyrzą- 
dzające szkodę (art. $442 \S 1$ zdanie drugie k.c.), bez względu na to, kiedy szkoda powstała lub się ujawniła.

Uwaga: Teza częściowo nieaktualna

\section{Uchwała SN z dnia 26 stycznia 2005 r., III CZP 42/04, OSNC 2005/9/149}

Ustanowiony $\mathrm{w}$ art. $118 \mathrm{kc}$. termin przedawnienia roszczeń o świadczenia okresowe stosuje się do roszczeń o odsetki za opóźnienie także wtedy, gdy roszczenie główne ulega przedawnieniu w terminie określonym w art. 554 kc. Roszczenie o odsetki za opóźnienie przedawnia się jednak najpóźniej z chwilą przedawnienia się roszczenia głównego.

\section{Uchwała SN z dnia 17 czerwca 2003 r., III CZP 37/03, OSNC 2004/5/70}

Roszczenie o odsetki za opóźnienie w zapłacie ceny wynikającej z umowy sprzedaży zawartej w zakresie działalności przedsiębiorstwa sprzedawcy przedawnia się z upływem lat dwóch (art. 554 kc.).

\section{Uchwała SN z dnia 21 października 1994 r., III CZP 136/94, OSNC 1995/2/38}

Przepisem szczególnym, o którym mowa w art. 118 kc., jest - w stosunku do roszczeń związanych z prowadzeniem działalności gospodarczej - każdy przepis ustawy przewidujący krótszy niż trzyletni termin przedawnienia.

\section{Uchwała SN z dnia 24 czerwca 1961 r., I CO 16/61, OSNC 1963/9/187}

1. Czynność prawna dotycząca majątku małoletniego, dokonana przez przedstawiciela ustawowego bez uprzedniego zezwolenia władzy opiekuńczej, wymaganego przez przepisy art. $58 \S 1$ i 85 k.r. jest nieważna (art. 41 p.o.p.c.) i nie może być konwalidowana.

2. Czynność prawna dwustronna, dokonana przez małoletniego, ograniczonego w zdolności do czynności prawnych bez wymaganej prawem zgody przedstawiciela ustawowego może być konwalidowana przez potwierdzenie czynności bądź przez przedstawiciela ustawowego (art. $53 \S 1$ p.o.p.c.), gdy chodzi o czynność objętą dyspozycją art. 58 § 1 i 85 k.r. za uprzednim zezwoleniem władzy opiekuńczej na takie potwierdzenie, bądź przez małoletniego po uzyskaniu przez niego pełnej zdolności do czynności prawnych (art. $53 \S 2$ p.o.p.c.). 


\section{Wyrok SN z dnia 13 marca 2009 r., II CSK 533/08, LEX nr 494009}

Sprzeczne z zasadami współżycia społecznego, w szczególności zaś z zasadą zapewnienia obywatelowi ochrony prawnej, z której może on rzeczywiście skorzystać, byłoby dopuszczenie sytuacji, w której nie może się on ubiegać naprawienia bardzo poważnej i pociagającej za sobą liczne konsekwencje szkody na osobie dlatego, że o poniesionym uszczerbku na zdrowiu, z przyczyn, za które nie ponosi żadnej odpowiedzialności, dowiedział się zbyt późno.

\section{Wyrok SN z dnia 27 czerwca 2001 r., II CKN 604/00, OSNC 2002/3/32}

Sąd wyjątkowo może nie uwzględnić zarzutu upływu terminu przedawnienia roszczenia - także wynikającego ze stosunku pomiędzy przedsiębiorcami - jeżeli jego podniesienie przez pozwanego jest nadużyciem prawa.

\section{Wyrok SN z dnia 15 stycznia 1991 r., III CZP 75/90, OSNC 1991/5-6/68}

Sześciomiesięczny termin do złożenia oświadczenia o przyjęciu lub odrzuceniu spadku z ustawy rozpoczyna się - zarówno dla spadkobiercy ustawowego powołanego w testamencie do spadku, jak i dla pozostałych spadkobierców ustawowych - z dniem, w którym dowiedzieli się oni z właściwego źródła o tym, że testament $\mathrm{z}$ uwagi na niezachowanie prawem przepisanej formy jest nieważny (art. $1015 \S 1$ kc.).

\section{Postanowienie SN z dnia 14 czerwca 2005 r., V CZ 63/05, LEX nr 512034}

Artykuł 112 kc., do którego odsyła art. $165 \S 1$ kpc., ma zastosowanie tylko przy terminach ciagłych, a taki charakter mają terminy procesowe. Do ich obliczania nie można stosować art. 114 kc., który określa sposób obliczania terminu oznaczonego w miesiącach i latach, gdy ciagłość terminu nie jest wymagana.

\section{Postanowienie SN z dnia 13 lutego 1997 r., I CKN 73/96, LEX nr 50572}

Zarówno terminy ustawowe, jak i terminy sądowe dla dokonania czynności procesowych mają tę wspólną cechę, że nie mogą rozpocząć biegu w razie, gdy sąd nie wskaże stronie ich długości.

\section{Postanowienie SN z dnia 25 czerwca 1996 r., II CRN 214/95, LEX nr 26273}

Nabycie spadku przez osobę niemająca pełnej zdolności do czynności prawnych, a więc m.in. przez osobę małoletnią (art. 11 kc.), z wyjątkiem sytuacji, gdy następuje na podstawie oświadczenia o przyjęciu spadku wprost, które jednakże 
wymaga zgody sądu opiekuńczego (art. $101 \S 3$, art. 156 i art. $178 \S 2$ k.r.o.), jest zawsze bezpłatnym przysporzeniem, którego rozmiar określa ustawa (przy dziedziczeniu ustawowym) lub treść testamentu (przy dziedziczeniu testamentowym), bądź - gdy długi spadku są równe wartości stanu czynnego spadku lub go przewyższają - wprawdzie do przysporzenia nie prowadzi, ale nie powoduje żadnego uszczuplenia majątkowego (art. $1015 \S 2 \mathrm{w}$ związku z art. 1012 kc.). Dlatego w postępowaniu o stwierdzenie nabycia spadku, w którym małoletnie dziecko reprezentowane jest przez jedno z rodziców będące też spadkobiercą, regułą jest, iż nie zachodzi między nimi kolizja interesów, wykluczająca w myśl art. 98 § 3 k.r.o. w związku z $\S 2$ tego artykułu reprezentację dziecka przez tegoż rodzica. Jednakże wyjątkowo, gdy np. rodzic reprezentujący dziecko domaga się na swoją rzecz udziału w spadku ponad wynikający z treści testamentu albo podważa ważność testamentu sporządzonego na rzecz dziecka, działanie jego zmierza do uszczuplenia udziału w spadku przypadającego dziecku lub nawet do pozbawienia go tego udziału. Tak też działanie rodzica należy ocenić, gdy dochodzi on - obok dziecka - stwierdzenia dziedziczenia gospodarstwa rolnego wchodzącego w skład spadku na swoją rzecz, w okolicznościach nasuwających uzasadnione wątpliwości co do tego, czy spełnia warunki uprawniające go do tego dziedziczenia. W wymienionych sytuacjach kolizja interesu dziecka i rodzica sprzeciwia się reprezentowaniu dziecka przez tego rodzica. Jeżeli wówczas dziecka nie może reprezentować drugie z rodziców, powinien je reprezentować kurator ustanowiony przez sąd opiekuńczy (art. 99 k.r.o.).

\section{Postanowienie Sądu Apelacyjnego w Krakowie z dnia 1 października 2008 r., II S 6/08, KZS 2008/11/70}

1. Naruszenie prawa do osądzenia sprawy bez zbędnej zwłoki (przewlekłość postępowania) zachodzi nie tylko $\mathrm{w}$ razie indywidualnej sytuacji opieszałości działań sędziego czy jego sekretariatu, ale i wskutek wadliwej organizacji pracy, w tym nieprawidłowego założenia, że sprawy obszerniejsze będą rozpoznawane w postępowaniu odwoławczym po upływie roku od wniesienia, a sprawy mniej obszerne bez zwłoki, co sprowadza się w praktyce do czterech miesięcy od ich nadesłania. Nie negując potrzeby dłuższego przygotowywania się do podjęcia decyzji w sprawach obszernych, Sąd Apelacyjny wyraża przekonanie, że nie powinno to prowadzić do tak dużej zwłoki.

2. Nie można oczekiwać rozpoznawania sprawy niezwłocznie po jej wniesieniu. Żadne społeczeństwo nie byłoby w stanie utrzymać tak dużej ilości sędziów, jaka byłaby po temu niezbędna. Niezwłoczne rozstrzyganie sprawy nie jest możliwe ani ze względów organizacyjnych (doręczenie stronom zawiadomień o miejscu i terminie rozprawy), ani nie byłoby to rozsądne wobec konieczności zapoznania się sędziów z materiałami sprawy, czasu dla ich rozważenia i podjęcia decyzji, wreszcie 
- jej uzasadnienia. Chodzi o to jedynie, by czynności te zabierały odpowiednią ilość czasu, to jest odbywały się bez zbędnej zwłoki, która wskazywałaby na bezczynność sądu lub bezproduktywność jego działań (KZS 11/05 poz. 39).

3. Stwierdzenie przewlekłości działania sądu nie oznacza każdorazowego przyznania za to odpowiedniej sumy pieniężnej. Ma ona pełnić rolę środka uzasadnionego słusznością i celowością, więc krzywdą jednostkową osoby, której prawo naruszono oraz celowością jej usunięcia. Gdy tego nie wykazano, nie ma czemu czynić zadość taką sumą pieniężną (zob. o tym w postanowieniu SA Wrocław z dnia 24 czerwca 2005 roku - KZS 1/06, poz. 83).

\section{Postanowienie Sądu Apelacyjnego w Krakowie z dnia 22 marca 2007 r., II S 1/07, KZS 2007/3/42}

Przewlekłość postępowania zachodzi, gdy jest ono długotrwałe, prowadzone rozwlekle i trwa ponad konieczność wyjaśnienia okoliczności faktycznych i prawnych niezbędnych do końcowego rozstrzygnięcia, będących w związku przyczynowym z działaniem lub bezczynnością sądu.

\section{Postanowienie Sądu Apelacyjnego w Katowicach z dnia 11 maja 2005 r., II S 26/05, LEX nr 151808}

Ustalenie zaistnienia przewlekłości postępowania nie jest zależne jedynie od upływu czasu i subiektywnych odczuć skarżącego, a jest wypadkową czynników obiektywnych oraz czasu niezbędnego do podejmowania działań zgodnych z obowiązującymi przepisami przewidującymi prowadzenie określonych procedur. Przewlekłość jest bowiem pojęciem mówiącym, iż jakieś zdarzenia, czy stany są nadmiernie rozciagnięte w czasie, rozwleczone i przedłużają się. Jest to, co oczywiste, pojęcie względne, a zatem zawsze musi być odnoszone do konkretnych realiów sprawy i przyjętego trybu postępowania. Jedynie nadmierne odstępstwa od czasu koniecznego do wykonania określonych czynności sądowych, prac i procedur mogą być uznawane za tworzące stan nieuzasadnionej zwłoki, o jakim mowa w ustawie $\mathrm{z}$ dnia 17 czerwca $2004 \mathrm{r}$.

\section{Słowa kluczowe: czas w prawie i postępowaniu administracyjnym}

\section{Wyrok NSA z dnia 16 maja 2007 r., I OSK 1080/06, LEX nr 342503}

Z obowiązującej konstytucyjnej zasady praworządności wynika, że w postępowaniu administracyjnym organy administracji publicznej obowiązane są stosować przepisy obowiązujące w dniu wydania decyzji do stanu faktycznego obowiązują- 
cego w dniu wydania decyzji. Od tej reguły mogą zostać wprowadzone odstępstwa przepisami przejściowymi.

\section{Wyrok NSA z dnia 26 lutego 2003 r., V SA 1131/02, OSP 2003/7-8/93}

glosa aprobująca: Łętowska E. OSP 2003/7-8/93

Zwłoka organów administracji publicznej w załatwieniu sprawy i naruszenie terminów określonych w art. 35 k.p.a. nie może powodować ujemnych skutków dla strony.

\section{Wyrok NSA z dnia 21 marca 2002 r., V SA 2019/01, LEX nr 109322}

1. Powoływane przez Zrzeszenie Właścicieli Nieruchomości pełnomocnictwo do ,zarządzania i administrowania” w imieniu właścicieli ich nieruchomością nie pozbawia ich przymiotu strony w sprawie o wymeldowanie i w następstwie tego pełnomocnictwa Zrzeszenie nie stało się stroną w sprawie.

2. Zrzeszenie Właścicieli Nieruchomości nie mogło być w sprawie administracyjnej o wymeldowanie pełnomocnikiem procesowym właścicieli już choćby z tego względu, że w myśl art. $33 \S 1$ k.p.a. pełnomocnikiem procesowym strony w postępowaniu administracyjnym może być jedynie osoba fizyczna.

\section{Wyrok NSA z dnia 8 marca 2001 r., IV SA 41/99, Wspólnota 2001/13/52}

Zgodnie $\mathrm{z}$ art. $33 \S 1$ kodeksu postępowania administracyjnego, pełnomocnikiem strony może być osoba fizyczna posiadająca zdolność do czynności prawnych, a więc zarząd stowarzyszenia nie może pełnić funkcji pełnomocnika.

\section{Wyrok NSA z dnia 21 czerwca 1996 r., I SAB 28/96, ONSA 1997/2/97}

Nowy termin załatwienia sprawy może być uznany za skutecznie wyznaczony w trybie art. $36 \S 1$ k.p.a., jeżeli zostanie wskazany przez organ właściwy do załatwienia sprawy zgodnie z art. 57 k.p.a. (tj. w dniach, tygodniach lub miesiącach) i z zachowaniem ogólnej zasady szybkości postępowania określonej w art. 12 k.p.a.

\section{Postanowienie NSA z dnia 24 lipca 2008 r., II OPP 20/08, LEX nr 493700}

Co do zasady postępowanie sądowe jest przewlekłe, jeżeli toczy się ponad 12 miesięcy. 
Postanowienie NSA $z$ dnia 15 sierpnia 1985 r., III SAB 7/85, OSP 1989/2/26

glosa: Borkowski J. OSP 1989/2/26

Jeżeli organ administracji państwowej wydał decyzję odmawiającą stwierdzenia nieważności zaskarżonej decyzji, to w następstwie wniesienia kolejnej skargi, którą organ załatwił w trybie art. 239 k.p.a., nie nastapiło wszczęcie postępowania administracyjnego i nie biegną terminy określone w k.p.a. dla załatwienia sprawy przez wydanie kolejnej decyzji. Skarga na bezczynność z tego powodu do NSA podlega odrzuceniu - jako niedopuszczalna.

\section{Wyrok Wojewódzkiego Sądu Administracyjnego w Białymstoku z dnia 4 czerwca 2008 r., II SAB/Bk 15/08, LEX nr 514413}

nietezowane

\section{Wyrok Wojewódzkiego Sądu Administracyjnego w Olsztynie z dnia 10 września 2008 r., I SA/OI 310/08, LEX nr 480304}

Nie można wywodzić z przepisu art. 121 Ordynacji podatkowej obowiązku powielania błędnego stosowania prawa i zakazu zmiany stanowiska po stwierdzeniu, że dotychczasowe orzecznictwo było niezgodne z prawem, w tym z prawem unijnym. Wręcz przeciwnie, w takiej sytuacji organ obowiązany jest zmienić swoje stanowisko i wydawać decyzje odpowiadające aktualnemu stanowi prawnemu. Obliguje do tego zasada praworządności wyrażona zarówno w Konstytucji RP w art. 7, jak i w Ordynacji podatkowej w art. 120.

\section{Wyrok Wojewódzkiego Sądu Administracyjnego w Warszawie z dnia 21 czerwca 2006 r., I SA/Wa 534/06, LEX nr 219233}

1. Samo zarządzanie nieruchomością w imieniu gminy nie czyni z zakładu budżetowego strony uprawnionej do wystapienia o pozwolenie na zmianę układu przestrzennego, brak jest bowiem przepisu w ustawie z dnia 21 sierpnia $1997 \mathrm{r}$. o gospodarce nieruchomościami (Dz.U. z 2004 r. Nr 261, poz. 2603 ze zm.), który upoważniałby tę jednostkę organizacyjną nieposiadającą osobowości prawnej do występowania w imieniu gminy w tego typu postępowaniach.

2. Rozstrzygnięcie o prawach i obowiązkach jednostki niebędącej stroną poprzez skierowanie decyzji nie do właściciela nieruchomości, lecz jej zarządcy, spełnia przesłankę nieważności decyzji określoną w art. $156 \S 1$ pkt 4 k.p.a.

3. Wskazanie jako adresata decyzji pełnomocnika, jak również skierowanie decyzji do pełnomocnika osoby prawnej jest równoznaczne ze skierowaniem decy- 
zji do osoby niebędącej stroną w sprawie i powoduje, że decyzja taka jest dotknięta wadą nieważności w rozumieniu art. $156 \S 1$ pkt 4 k.p.a.

\section{Postanowienie Wojewódzkiego Sądu Administracyjnego w Gdańsku z dnia 19 sierpnia 2004 r., II SAB/Gd 90/02, LEX nr 299477}

Na niewydanie przez Samorządowe Kolegium Odwoławcze postanowienia w trybie art. $37 \S 1$ k.p.a. nie przysługuje skarga do sądu administracyjnego na bezczynność tego organu w zakresie objętym art. 37 § 1 k.p.a. Postanowienie takie nie kończy bowiem postępowania administracyjnego, nie rozstrzyga sprawy co do istoty, ani nie służy na nie zażalenie, tak jak wymaga przepis art. $3 \S 2$ pkt 2 p.p.s.a. Zatem skarga na bezczynność organu polegającą na niewydaniu postanowienia w trybie art. 37 k.p.a. nie przysługuje, zgodnie z przepisem art. $3 \S 2$ pkt 8 p.p.s.a.

\section{Słowa kluczowe: czas w prawie publicznym}

\section{Postanowienie SN z dnia 13 maja 2008 r., III SK 39/07, ZNSA 2008/5/118}

Obowiązywanie lub nieobowiązywanie decyzji tymczasowej w dacie wyroku nie ma przesądzającego znaczenia dla orzekania przez Sąd o obowiązkach przedsiębiorcy, nawet gdy zostały one określone decyzją tymczasową.

Wyrok Sądu Ochrony Konkurencji i Konsumentów z dnia 12 listopada 2003 r., XVII Ama 129/02, Wokanda 2004/7-8/98

Zgłoszeniu Prezesowi Ochrony Konkurencji i Konsumentów podlega, pod rygorem nałożenia kary pieniężnej, zamiar koncentracji przedsiębiorców, nie zaś fakt dokonania tej czynności.

Opracowata: Justyna Matys 